\title{
The Impact of Community Expectations on Corporate Community Involvement Disclosures in the UK
}

${ }^{1}$ kemi C. Yekini*, ${ }^{2}$ Ismail Adelopo, ${ }^{1}$ Emmanuel Adegbite

\author{
${ }^{1}$ Department of Accounting and Finance, \\ Faculty of Business and Law \\ De Montfort University, \\ Leicester, \\ LE1 9BH, \\ UK \\ ${ }^{2}$ Department of Accounting, Economics and Finance \\ Faculty of Business and Law \\ University of West England \\ Bristol \\ BS16 1QY \\ United Kingdom
}

* Corresponding author: Dr. Kemi C. Yekini Email address: kyekini@dmu.ac.uk

Telephone: 07766578894 


\title{
The Impact of Community Expectations on Corporate Community Involvement Disclosures in the UK
}

\begin{abstract}
Despite increase mistrust between corporations and societies in the aftermath of the global corporate misbehaviours, the literature examining the impact of community concerns on corporate communications is undeveloped. Our paper is timely; it contributes to the literature on corporate social responsibility (CSR) by considering the impacts of community expectations on Corporate Community Involvement Disclosures (CCID) using a ten-year panel study. We advance CSR communication research by providing a fresh theoretical perspective - media-agenda-setting theory - to the broad CSR debate and the CCID subset of this debate. Our findings support the media-agenda theoretical expectation and provide important practice and policy recommendations for improving interactions between corporations and their communities.
\end{abstract}

Keywords: Community involvement disclosures; Community expectations; Media Agenda-setting theory; Panel study.

JEL classifications: C26; C33; D83; G01; M14; M41 


\section{Introduction}

An extensive literature on the interactions between the corporation and its external environment points to the importance of achieving congruence between them, and to the roles of effective communication in finding a fit between corporate action and corporate community approval (Brown and Deegan, 1998; Islam and Deegan, 2010; Suchman, 1995; Deegan and Gordon, 1996). Understanding the link between community expectations and corporate community involvement disclosures (CCIDs) is important for many stakeholders in the corporate environment. This is because clarity on this link could enhance the interactions between the firm and its community and facilitates firms' access to societal resources due to enhanced legitimacy. Despite the acknowledgements in the literature of the importance of communication, the literature examining the impact of community expectations on corporate communications is very undeveloped (Islam and Deegan, 2010; Deegan et al., 2002). In an attempt to address this gap, this study departs from the bulk of the literature in this space by adopting the lens of the media agenda-setting theory to investigate the impact of community expectations on CCID.

Using the media agenda-setting theory in providing explanations for the role of community expectations in corporate voluntary disclosures helps us to integrate two important research areas that are currently considered separately - Social communication and corporate voluntary disclosures. In particular, we used the literature on social communication and media agenda-setting to enrich the literature on corporate voluntary disclosure, especially voluntary CCIDs. This is an important, yet overlooked aspect of the corporate disclosure literature. Moreover, the recent global corporate governance (CG) and financial crises provide a suitable opportunity to test whether corporate communications might indeed be insensitive to community expectations. This is because the consequences of the crises may be perceived to have inadvertently created a gap between corporate social performance as reported in the annual reports of companies and community expectations. This implies a situation whereby corporate behaviour has fallen below societal expectations of what is acceptable. According to Suchman (1995), this is an example of a disconnection between the firm and its community, which could challenge firms' continued legitimacy in the society. Suchman (1995) also argues that firms need to address this gap through a number of means including improving communication with its conferring publics. Yekini et al., (2015, p. 251) further argue that the 'firm needs to strengthen its societal acceptance through effective interaction with the society in which it operates'. Consequently, the main objective of this study is to examine whether and how community expectations influence CCIDs.

We achieved this through a carefully constructed panel data of UK listed companies over a 10-year period from 2003-2012. The scope of the study covers both the CG and financial crises, allowing us to generate a deeper understanding of the effects of these events on corporate disclosure practices. Our study investigates whether the ensuing communications were a direct response to aggravated community expectations or if corporate disclosures in the annual reports are insensitive to such expectations. We undertook the study in the UK FTSE 350 Index, with a sample of 80 firms representing all industries on the exchange. We examined them over a ten-year period, thus having 800 firm-year observations. We collected data on CCID from the annual reports of the sampled companies as well as from articles on community issues published in print and electronic media from over 40,000 legal, news and business sources across the globe. These allowed us to provide additional international evidence on the determinants of corporate voluntary disclosure where principles rather than rules motivate compliance with disclosure requirements.

This study directly contributes to the literature on corporate voluntary disclosures, especially CCIDs. Whilst previous studies (Campbell et al., 2006; Bebbington et al., 2008; Toms, 2002; Hasseldine et al., 2005; Yekini and Jallow, 2012) have examined different determinants of corporate disclosure, we extend the literature by considering the impacts of community expectations on corporate voluntary disclosures. This is an important question in the context of the increased mistrust between corporations and societies in the aftermath of the recent global corporate misbehaviours. 
We also make methodological contributions to the literature on voluntary corporate social disclosure. Previous studies concentrate on either a cross sectional analysis (Adams et al., 1998; Deegan et al., 2000) or a trend analysis of selected cases (Campbell, 2000) or the use of limited number of years (Watson et al., 2002). In contrast, our study uses panel data analysis, which combines both the cross sectional and the time series elements in a data, therefore allowing a more robust analysis (Jizi et al., 2014). Furthermore, nonparametric statistical analysis dominates the vast majority of extant studies in this area. Nonparametric techniques are generally less efficient than parametric analysis, even with normally distributed data (Bryman and Bell, 2007). We analysed the nexus between CCID and community expectation using advanced parametric techniques (i.e. panel data regression models). Vickers (2005) produces evidence that parametric techniques give more efficient results than their nonparametric equivalents.

We structured the rest of the paper as follows: the next section provides a review of relevant literature as well as the media agenda-setting theory, which helps to formulate our hypothesis. Section three describes the methodology adopted in the study. We discussed the findings in section four, while section five concludes the study, with some recommendations for future research.

\section{Previous studies, theory and hypothesis}

\subsection{CSR and CSR Disclosure}

The extant literature has addressed several aspects of the CSR debate, including its historical development (Patten, 2013), motivation (Amaeshi, Adegbite and Rajwani, 2016) and types (Halme and Laurila, 2009) in varieties of capitalism. However, the boundary around the meaning and scope of what could be defined as CSR is severely blurred and it is increasingly difficult to agree on a generally acceptable definition of CSR. Despite the contentions, a number of descriptions and explanations serve as the basis for further discussions, and provide grounds for operationalising the concept in an empirical analysis. According to Halme and Laurila (2009: 237), corporate responsibility is the "policies and activities that go beyond mandatory obligations such as economic responsibility (being profitable) and legal responsibility (obeying the legislation and adhering to regulations)." McWilliams and Siegel (2001:117) defined CSR as "actions that appear to further some social good, beyond the interests of the firm and that which is required by law." These definitions highlight the altruistic dimension of CSR and show that CSR refers to what organisations do willingly beyond the primary objective of maximising profits and the requirements of law and regulations, for the benefits of their stakeholders.

Companies often disclose the extent of their CSR activities and as such, a significant number of studies have addressed the probity (Bachmann and Ingenhoff, 2016; Morsing, Schultz, and Nielsen 2008), medium and methods (Brown et al., 2009; Dhaliwal et al., 2011; Patten, 2012; Patten and Zhao 2014) of CSR disclosure. Whilst studies such as Morsing et al., (2008) cautioned firms on the communication of their CSR activities, other studies suggest that disclosure reduces firms' cost of capital (Dhaliwal et al., 2011), and impacts firms' legitimacy (Deegan, 2002). Due to increasing disclosure by companies, the scope of what constitutes CSR has expanded significantly overtime beyond the popular characterisation encompassing legal, economic, social and philanthropic responsibilities (Carroll, 1991). A number of recent studies have provided more nuance examples of what constitute CSR including for example, employee, human and environmental rights, and anticorruption efforts (Healy and Serafeim 2013; Beatty and Liao 2013; Adegbite and Nakajima, 2011), and more recently institutional entrepreneurship and filling of institutional voids (Amaeshi, et. al., 2016). An aspect of the CSR classifications that has enjoyed less attention in the CSR discourse both in terms of its essence and disclosure is the corporate community involvement activities. 


\subsection{Corporate Community Involvement}

Corporate community involvement (CCI) or what Rehbein and Schuler (2015: 794) referred to as 'corporate community program' is the participation of businesses in societal initiatives in a bid to meet the needs of the communities in which they operate (Yekini et al., 2015; Moon and Muthuri, 2006). It is far more than donations and charitable activities but includes granting stakeholders access to company's infrastructure, human resources and business activity. It entails committing significant time and company's resources to community projects. CCI is different from other corporate social responsibility (CSR) types because whilst these may be driven by the need to redress the negative externalities arising from a firm's operations, CCIs are distinct in their altruistic motives (Yekini et al., 2015). CCIs are characterised by actual involvement in the life of the society and the engagement of corporation in civic duties within their community of operation ${ }^{\text {[1] }}$ (Moon and Muthuri, 2006). The historical antecedents of CCI also make it distinctive from other CSR initiatives. Corporate involvement in societal life pre-dates current notions of CSR. Gilchrist (2003) observe that corporations were fundamental part of the fabrics of society in the late $19^{\text {th }}$ and early $20^{\text {th }}$ centuries. There were palpable connections between the firm and the society, and it was common for corporations to make their resources accessible to the society in which they operate. However, in the aftermath of the Second World War, there were noticeable gaps in corporate engagements with the society. This disconnect became even more apparent due to the devastating effects of the war. Especially, many national governments were unable to, unilaterally, address the consequences of the war, and relied heavily on corporations, as partners. Thus, in summary, unlike the broad CSR concept, CCI is a distinct and unique type of corporate engagement with its community and has a long historical note of corporations' tangible involvements and interactions with their society of operation (Rehbein and Schuler, 2015).

A growing number of studies (Campbell et al., 2006; Yekini et al., 2015; Rehbein and Schuler, 2015; Peloza and Falkenberg, 2009) have recognized the uniqueness of CCI activities and their difference to other types of CSR activities, because of their external outlook and their tangible interaction with the firms' external community. In this sense, Rehbein and Schuler (2015:796) note that corporate community programs (CCP) are "externally focused and explicitly intended to address a range of social issues, including community poverty, educational deficits, environment, and human health." A number of these studies also argue that CCID is grossly under-researched "despite its importance as a broadly conceived stake-holder group (Campbell et al., 2006, p. 97). A related and possibly a more fundamental issue with the broad CSR debate, and in particular the scanty CCI literature, is the lack of adequate theorisation (Basu and Palazzo, 2008), and limited conceptual basis beyond the traditional theoretical framework such as stakeholder and legitimacy theories, that have dominated CSR discourse. In addressing this, the next sub-section discusses the media agendasetting theory, and develops the study's hypothesis.

\subsection{Media Agenda-Setting Theory}

A growing number of studies (Basu and Palazzo, 2008; Bebbington et al., 2008; Hooghiemstra, 2000) have called for new theoretical perspectives to enhance the quality of the CSR literature. In particular, theoretical underpinnings from adjoining social science fields, including psychology, media studies, anthropology, sociology and politics can help to enrich our collective understanding of the broader CSR debate. This study uses media agenda setting theory to generate deeper insights into the role of the media in CCID.

Media agenda-setting theory has its roots in the work of McCombs and Shaw (1972) who suggested that people do not respond directly to events in the real world but that their reactions to 
events depend on the image furnished by the media. The theory proposes that the media create meanings and knowledge for the society, and set the stage for the content of its discourse, and the perception of the population on issues. It focuses on the explanations of the rise and fall of social, political, and economic issues in the media and public policies (McCombs et al., 2014; Weaver et al., 1981; McCombs and Shaw, 1972). The theory suggests that there is a strong direct correlation between media agenda and issues salience in the public opinion (Garcia-Sanchez et al., 2014; Dearing and Roger, 1996; McCombs and Shaw, 1972). This implies that the media choices about the importance or otherwise of an issue or debate reflect highly on what ultimately becomes the most important issue to the public (Garcia-Sanchez et al., 2014). The theory also implies that although an issue may enjoy wide publicity and attention elsewhere, its selection in the media is a conscious and calculated decision by specific media outlets (Scheufele and Tewksbury, 2007). This is because the media do not have unlimited space, airtime or 'web-space' to accommodate news (Gans, 1979; Korthagen, 2015) and therefore take strategic decisions on which news item to feature and how to report them. In other words, the media influences public discourse through their selection and framing of news items.

Thus, the media play an influential role in developing the image and perceptions created in people's mind. This means that the media has the power to mediate audiences' attention and problematise issues that consequently form the basis of public discourse. In this light, and as early as 1963, Cohen (1963, p.13) observe that the media 'may not be successful much of the time in telling its readers what to think, but it is stunningly successful in telling its readers what to think about'. This statement supports the perception that the media is very influential in managing social actors' cognitive processes. However, in his critique of the media agenda setting hypothesis, Entman (1989, p.349) argues that 'nobody, no force, can successfully tell people what to think'. He further argues that, irrespective of the medium of control or method of disseminating the message, 'control over others' thinking can never be complete' (p.349). He argues that the interaction between the media and public opinion generated through this process showed the interdependence between the parties. On the other hand, proponents of the media agenda-setting theory contend that the media has substantial influence on what audience think, arguing that there is a direct relationship between media agenda setting and issue salience in the public domain. This view is consistent with McCombs and Shaw's (1972) conclusion that the main effect of the news media is agenda setting, because they tell people what to think about and how to think about it. Similarly, McCombs (2000) concludes that 'the power of the news media to set a nation's agenda, to focus public attention on a few key public issues, is an immense and well documented influence' (p. 1).

\subsubsection{Media Agenda Setting, Public Expectations and the Corporation}

Evidence from previous studies (Wanta et al., 2004; Ader, 1995; Fang and Peress, 2009; Aerts and Cormier, 2009; Brown and Deegan, 1998) on agenda setting theory supports the perceptions of a positive correlation between media coverage and public expectation on issues. These include studies in politics and elections (McCombs and Shaw, 1972), foreign policies (Wanta et al., 2004), pollution (Ader, 1995), environmental performance (Aerts and Cormier, 2009), stock market performance (Fang and Peress, 2009) and health (Nerlich and Halliday, 2007). According to Brown and Deegan (1998: 25) "in terms of causality, increased media attention is believed to lead to increased community concern for a particular issue”. Similarly, Aerts and Cormier (2009: 3) assert that; "Media research within the agenda-setting paradigm (Carroll \& McCombs, 2003; McCombs \& Shaw, 1972) demonstrates a close alignment between the content of public media and public opinion (or the degree of salience that different topics have for the general public), corroborating the assertion that public media are actively involved in public impression construction processes”. 
Furthermore, Nerlich and Halliday (2007) focused on how media coverage generates community expectations. The authors argued that media coverage has performative force on different actors within the society. This implies that news items and the linguistic attributes of their media coverage which lead to community expectations also elicit response from their recipients. This idea of the performative force of the media coverage on issues is consistent with an increasing number of recent literature which sees the media as part of the institutional legitimisation process in the society. For example, according to Aerts and Cormier (2009:3) the media is "an institutional intermediary" that specialises in the dissemination of information to organisations, and the evaluation of their contributions to the society. Consequently, the media has the power to facilitate corporate legitimacy due to its believability, reach and resources, since it provides a mean through which the public filters its perceptions on issues, arriving at a common impression irrespective of the variety of views (Aerts and Cormier, 2009).

However, while the media is important in the corporate legitimisation process through its performative force, it also requires societal legitimacy based on the symbolic social contracts between organisations and the society in which they operate (Suchman, 1995: Islam and Deegan, 2010). This implies that the relationship between the media, corporations and the society is dynamic, iterative and mutually dependent. In this sense, whilst the media coverage of a pertinent issue may lead to the generation of expectation which elicits action from corporations, corporate activities are also capable of generating media coverage which could further shape public opinion (see Figure 1 for illustration), yet the issues of media regulation and accountability remain highly contentious (van der Wurff and Schonback, 2014; Brants and De Haan, 2010). Thus, it is probably impossible to adequately tease out the intricate relationships amongst the corporation, society and the media in just one study. Consequently, the current study focuses only on the impacts of community expectation on CCID. The next section motivates the study's hypothesis.

\subsubsection{Media Agenda-Setting Theory and CCI}

In the context of a firm's community of operation, and the role of the media in agenda setting in CCI activities, previous studies (Ader, 1995; Brown and Deegan, 1998; O’Donovan, 1999; Deegan et al., 2002) show that the media usually generate public awareness on issues. They argue that the attention the media give to a particular issue could lead to public awareness and expectations (Deegan et al., 2002). Accordingly, Deegan et al., (2002, p.314), the 'media are not seen as mirroring public priorities; rather they are seen as shaping them'.

Furthermore, Ader (1995) argues that the public requires the media to inform them of the importance of an issue to help them form their opinion. In other words, the awareness of an issue through the media will normally precipitate the development of community expectations. For instance, Ader (1995) finds that media coverage on pollution has a direct effect on the importance attached to it by the public. O'Donovan (1999) finds that corporate management is aware that media publicity can affect public perception and therefore uses disclosure in annual reports to shape public perception. Similarly, Deegan et al., (2002) find that the issues that attracted the largest media coverage also represented the largest disclosed issues in BHP annual reports between 1983 and 1997. They argue that these issues attracted such a level of disclosure because management perceived that they have generated community expectations to which management is obliged to respond. These studies suggest a direct positive relationship between media coverage and issue salience as reflected in increased public expectations. Against this background, we argue that since media coverage influences the awareness of the community-stakeholders' group to concerns within the community, and due to the performative force in the coverage, companies respond to the perceived increased concern and community expectations through increase disclosure in order to retain/maintain corporate legitimacy. The media agenda-setting theory also precludes the possibility of a firm to 
self-select its coverage in the media through event such as press briefing or press announcement. This is because media houses take deliberate and calculated decision on which news item to feature (Korthagen, 2015; Scheufele and Tewksbury, 2007; Gans, 1979). Furthermore, based on the agendasetting theory (McCombs and Shaw, 1972), and given Deegan et al., (2002) evidence of a positive relationship between media coverage and the extent of the coverage of an issue in corporate disclosure, it can be argued that a positive relationship subsists between community expectations and CCIDs as companies respond to increased expectations from their communities of operation. Therefore, our hypothesis is formally presented and depicted in Figure 1:

\title{
Hypothesis: There is a positive relationship between the volume of CCID and community expectations.
}

\author{
$[<<<<$ Figure 1 about here $>>>>>]$
}

In testing this hypothesis, we controlled for the effects of CG variables and other firm-specific characteristics based on the literature as presented next.

\subsubsection{Control variables}

Board size has featured in several previous studies (Yermack, 1996; Wilson and Lombardi, 2001). Board size could facilitate diversity in the board's deliberations (Song and Windram, 2004), especially as it may enhance the representation of community interests on the board which may prevent groupthink on issues (Yekini et al., 2015). Such community representatives could therefore provide a link between the firm and the community of operation, allowing the firm to have a deeper understanding of community concerns. Previous studies have reported mixed findings on the relationship between board size and voluntary corporate disclosure. Studies such as Wilson and Lombardi (2001) and Webb (2004) report a positive relationship. On the other hand, Yermack (1996) and Song and Windram (2004) report a negative relationship between voluntary disclosure and board size. We anticipate a positive relationship between board size and the extent of CCID, since larger board may have the manpower to ensure corporate monitoring relating to disclosure ${ }^{\text {[2] }}$ (Webb, 2004).

Board meeting frequency is indicative of its activeness and diligence (Cormier et al., 2010). Frequent board meetings could allow effective oversight functions on the type, nature and content of corporate communications, including CCID. Diligent boards, through frequent meetings, are in a better position to understand community expectations and act upon them compared to boards that rarely meet. Previous studies report conflicting results in respect of the relationship between board meeting frequency and voluntary disclosures. For example, Evans et al. (2002) report a negative relationship between board meeting frequency and voluntary disclosures, while Karamanou and Vafeas (2005) report a positive relationship. We anticipate a positive relationship on the argument that boards that meet more frequently enhance corporate disclosure.

Board independence is the proportion of independent non-executive directors to the total number of directors on the board. Board independence is crucial because it is expected that it will enhance directors' objectivity and ability to protect the interests of shareholders in boards' decisions. Previous studies (Webb, 2004; Ajinkya et al., 2005) report a positive relationship between board independence and voluntary disclosures ${ }^{[3]}$. In terms of CCID, we also expect a positive relationship because CCIDs are indicative of the interactions between the firm and its community of operation and they are therefore likely to enhance directors' individual and collective reputation and human capital worth. 
Furthermore, the unitary board system in the UK functions with the help of a number of board level committees, which support the activities of the main board. It is now commonplace for UK companies to have audit, nominations, remuneration, risk management, and some have disclosure and CSR committees. However, with the exception of the audit committee, there are limited studies on the impacts of the board level committees on corporate activities such as corporate voluntary disclosures, despite their potential to influence corporate transparency and accountability to various stakeholders. We controlled for the presence of risk management as well as disclosure and CSR committees for their direct relevance to CCID and to start to redress the lack of attention given to other board level committees in corporate disclosure studies. We anticipate positive relationships between the presence of these board level committees and the volume of CCID.

On firm size, previous studies report a positive relationship between firm size and voluntary disclosures (Hackston and Milne, 1996; Adams et al., 1998; Campbell et al., 2006; Garcia-Castro et al., 2010). Large firms have the resources to make voluntary disclosures, they have more visible presence in the community and their impacts are more likely to be noticeable than smaller firms. Based on this as well as the evidence from previous studies, we anticipate a positive relationship between firm size and the volume of CCID. Consistent with Hackston and Milne (1996), we measure firm size as the log of market capitalisation.

On firm performance, the relationship between firm performance and corporate disclosure is ambiguous. For example, whilst some studies report positive relations (Haniffa and Cooke, 2002), others have reported negative or no relationship at all (Ho and Wong, 2001; Eng and Mak, 2003). Profitable firms are in a better position to make additional voluntary disclosures compared to poor performing firms (Haniffa and Cooke, 2002; Bebbington et al., 2008) because they can afford it, and they have a good news ${ }^{7}$ factor that could motivate additional voluntary disclosure compared to poor performing firms. Based on this as well as previous findings, we anticipate a positive relationship between firm performance and volume of CCID.

On leverage, previous studies (Mangena and Pike, 2005; Tsamenyi et al., 2007; Garcia-Castro et al., 2010) argue that disclosure is sensitive to corporate leverage. Creditors prefer additional relevant information to less because more disclosure enhances corporate transparency and increases creditors' confidence (Mangena and Pike, 2005; Tsamenyi et al., 2007). More CCID can further enhance corporate transparency, since the cost of borrowing is likely to be different for firms, based on their level of transparency (Garcia-Castro et al., 2010). In view of this, we anticipate a positive relationship between firms' leverage and the volume of CCID.

On age, consistent with previous studies (Li et al., 2008; Haniffa and Cooke, 2002), we anticipate that older firms are likely to enjoy enhanced corporate status and confidence. This could boost corporate reputation than younger firms who may be relatively unknown and less trusted (Li et al., 2008). Furthermore, firms with long listing age are likely to have developed a clear strategy for corporate communication and are therefore more likely to consider CCID important. Previous studies (Li et al., 2008; Haniffa and Cooke, 2002) report positive relationships between firms' listing age and volume of corporate communications. Consistent with these arguments, we anticipate a positive relationship between firms' listing age and volume of CCID.

Finally, we controlled for the influence of other CSR disclosures (CSRD). Studies such as Toms (2002); Hasseldine et al., (2005); and Bebbington et al., (2008) all argue that reputation management is one of the key motivations for CSRD. For instance, Toms (2002) argue that CSR activity is an intangible asset and that its disclosure can help to build environmental reputation and reports an association between CSRD and corporate environmental reputation. Hence, as managers are inadvertently pressured to produce CSR reports in order to show their firms' social responsibility and thus improve corporate image, they are likely to report social responsibility across all CSR themes including CCID. We therefore anticipate a positive relationship between the disclosure of other CSR issues and CCID. 


\section{Methodology}

\subsection{Sample and Data}

This study focuses on a sample of FTSE 350 companies. We used the FTSE350 index because it is representative of the spread of industries in the UK. We classify the companies on the FTSE 350 into ten strata, using the Industrial Classification Benchmark (ICB) structure and code index. The ten industries include Oil and Gas, Basic Materials, Industrials, Consumer goods, Health care, Consumer services, Telecommunications, Utilities, Financials and Technology. We draw our sample from all the industries to ensure representation and enhance the reliability of the investigation. Our sample contained only companies on the London Stock Exchange as at January 2003 and that have all the required data for the variables in our model to ensure a balanced panel. We randomly selected ten companies from each industrial sector. We used all the companies in a sector if the sector has less than ten companies. This leaves us with a final sample of 80 companies, which we followed for a ten-year period from 2003-2012. This gives 800 firm-year observations which were used in this study.

We collected data on CCID from the annual reports of the sampled companies and measured the volume of CCID through the number of word counts on CCI activities. We used the number of articles on community issues published in print media available on the Lexis-Nexis Library for the period of the study to proxy for community expectations. This library provided access to a large database of searchable up-to-date documents from over 40,000 legal, news and business sources across the globe. We collected all the other data used in the study from DataStream and from the annual reports where this was not available on DataStream.

We used content analysis to derive both our dependent variable and the measure of community expectations variable. Content analysis is a systematic and objective means of describing and quantifying phenomena' (Elo and Kyngas, 2008: 108). As a research technique, content analysis has enabled us to make 'replicable and valid inferences from texts ... to the contexts of their use' (Krippendorff, 2004, p.18). A number of studies in accounting and finance (Guthrie et al., 2004; Hackston and Milne, 1996; Milne and Adler, 1999; Hooks and van Staden, 2011) have used content analysis both as a method of collecting and analysing data. This method has also been used in diverse ways to analyse narrative contents in annual reports. These include: sentence count (Hackston and Milne, 1996; Deegan et al., 2000); word count (Adams et al., 1998; Campbell et al., 2006) and constructing quality score index (Freedman and Stagliano, 2008; Yekini et al., 2015). The outputs from content analysis have been found to be valid and reliable especially when coding instruments are used with well specified decision rules and coding categories of information (Milne and Adler, 1999).

Content analysis was particularly useful in this study as it allowed for the construction of analytical categories of the contents of CCID in each annual report and, thus, allowed quantitative analyses. We defined the coding categories as precisely as possible with clear decision-rules and criteria. This is to ensure that the categories are mutually exclusive and exhaustive, and that classifications into categories are not discretionary (Ingram and Frazier, 1980; Bryman and Bell, 2007), thereby allowing for reproducibility. Coding was done over several months by two experienced researchers. We used inter-coder rating to reduce subjectivity and to improve validity (Krippendorff, 2004) ${ }^{[4]}$. While differences in individual experiences and orientation may make coding difficult despite clarity in coding instructions, we followed Milne and Adler's (1999) suggestions that maintaining very clear and tested decision rules and comparability over time lead to consistency in coding thereby improving accuracy and believability of the investigation. 


\subsection{Measurements}

The dependent variable is the volume of CCID in annual reports, while the main independent variable is community expectations. Although companies also report their CCI activities using alternative avenues including standalone sustainability reports (Thorne et al., 2014), consistent with Yekini et al., (2015), our study focused on the disclosure in the annual report because it is the most reliable and statutorily required means of communication by companies to their various stakeholders (Jenkins and Yakovlena, 2006). Furthermore, even where firms communicate their social information through other means, they also provide similar information in their annual reports. We also focused on the annual report because standalone and other avenues of social disclosures are not standardised. In particular, firms disclose in them as they wish and these alternative avenues may suffer from credibility issues, because unlike annual reports, companies do not have to audit their social disclosures (Jenkins and Yakovlena, 2006). Coupland (2006) also expressed concerns that separating financial information from social information could create distance in these sources of information and give prominence to financial information over social disclosure. Furthermore, our coding results of a sample of both annual and standalone reports were similar, supporting our decision to focus on the annual report.

Moreover, we measure CCID in terms of its volume for a number of reasons. Firstly, the debate on a superior disclosure measure is inconclusive (Botosan, 2004; Beattie et al., 2004; Hasseldine et al., 2005, Beretta and Bozzolan, 2008; Yekini and Jallow, 2012). Secondly, in deciding to use disclosure volume, we were guided by the fact that the fundamental criterion in deciding the appropriate measurement approach should be the study's objective (Gray et al., 1995; Hackston and Milne, 1996; Guthrie et al., 2003 \& 2004). The focus of our investigation was on the preponderance of CCID and news in the media and whether these generate disclosure expectations on listed firms in the UK.

We measured volume of CCI disclosed in annual reports using word count as the unit of measurement (Campbell et al., 2006). We considered the volume of disclosure as the total disclosure on community activities. We copied and pasted these disclosures into a Word document in order to count the number of words used, using Microsoft Software - Word documents. We considered disclosures on community involvement based on the theme in the disclosure or if a statement contains community and/or social involvement. We considered any statement reporting any form of community sponsorship activities, or any sponsorship of schools, health, arts and sporting activities as CCID. We also considered all employee involvements with the community as CCID, if the company's support is apparent, in addition to business-in-the-community award/secondment of staff. However, we considered only expressly stated disclosure and did not assume disclosure if not clearly stated. Furthermore, we did not consider any statement indicating that the company's community activity complies with governmental regulatory standards as disclosure to ensure that disclosure remains voluntary. Similarly, we did not include the disclosure of political or charitable donations in the directors' report since they are mandatory disclosures.

Consistent with previous studies, and as discussed in the last section, we measured community expectation with reference to media coverage on community issues. Accordingly, we obtained word counts of all relevant articles in the print media mentioning corporate involvement in community related issues such as community development, healthcare, the arts and educational sponsorship and scholarships from 2003 to 2012 from the LexisNexis Library. To ensure an adequate reflection of media coverage on community issues, we used all UK national and regional newspapers having wide circulations and present in the database from 2003 to 2012 (Appendix A). We recognise the lag between media coverage of an issue and firms' response by introducing a lag into our model to account for this reaction time in addition to using the variables contemporaneously. 


\subsection{Estimation Model}

We used a fixed effect (FE) model suitable for the panel nature of our data. FE models assume that the time invariant unobservable heterogeneity variable is unique to each firm and these are consolidated in the model's intercept. This ensures that only time variant factors account for the changes in the dependent variable (Greene, 2008).

In addition to these assumptions however, we carried out further post-estimation tests to examine the validity of the FE assumptions and its efficiency in dealing with the problems of heteroskedasticity by performing the Hausman test (see Appendix B). The results of the Hausman test support the use of the FE model by rejecting the null hypothesis of no correlation between the explanatory variables and the random effect model. Our main model with all the variables is as follows:

$$
\begin{aligned}
\text { LnCCIDit }= & \alpha_{0}+\beta_{1} \text { LnCOMNEWSit }-1_{1}+\beta_{2} \text { BODMETit }+\beta_{3} \text { BODCOMPit }+\beta_{4} \text { BODSIZit }+ \\
& \beta_{5} \text { RISKCOMit }+\beta_{6} \text { DISCOMit }+\beta_{7} \text { CSRCOMit }+\beta_{8} \text { LnOTHCSRDit }+ \\
& \beta_{9} \text { LnMCAPit }+\beta_{10} \text { ROEit }+\beta_{11} \text { LEVit }+\beta_{12} \text { AGEit }+ \text { Cit --- }
\end{aligned}
$$

The definitions of the variables in this model are summarised in Table 1.

$$
[<<<<\text { Table } 1 \text { about here }>>>>]
$$

\section{Results and Discussions}

\subsection{Summary Statistics}

Tables 2 and 3 present the summary statistics for our sample. In Table 2, on average, firms disclosed 476 words on CCID per year. The disclosures range from 0 to a maximum of 3271, while 1900 words were disclosed for other CSR themes such as human resources, environmental issues, amongst others, with disclosures ranging from 0 to a maximum of 12400 words.

$$
[<<<<\text { Table } 2 \text { about here }>>>>]
$$

The print media used an average of 7300 words per year to report on community issues during the sample period. On average, the board members of most of the companies sampled comprised of $62 \%$ non-executive directors (BODCOMP). This is similar to 68\% board independence reported by Elzahar and Hussainey (2012). The average firm in the sample has ten directors on the board. Board meeting frequency (BODMET) ranged from 3 to 16 meetings with most companies having an average of 8 meetings per year. Market capitalisation for companies sampled ranged between £6m and $£ 162 \mathrm{bn}$ with the average in the region of $£ 9 \mathrm{bn}$. The distribution of market capitalisation statistics suggests that the sample represents a wide range of companies of different sizes. This is important for representation and reliability of the study. Furthermore, the performance measure (ROE) was approximately $16 \%$ for most companies in the sample. Gearing ratio for most companies was in the region of 39.5\%. The average listing age of companies in the sample was approximately 23 years with some as old as 65 years. On average, 33\% of sampled companies had a CSR committee, while $22 \%$ had a disclosure committee and $31 \%$ had a standalone risk committee during the period covered 
in the study. Jarque-Bera and Shapiro-Wilk tests confirmed the absence of extreme Skewness and Kurtosis, and showed that the data is normally distributed.

$$
[<<<<\text { Table } 3 \text { about here }>>>>]
$$

\subsection{Correlation Matrix}

The correlation matrix in Table 3 shows a low correlation between the explanatory variables. Although market capitalisation (MCAP) shows a slightly high positive correlation of 0.54 with BODSIZ, this is below the threshold of 0.80 often considered problematic for empirical analysis (Tabachnick and Fidell, 2007). Nevertheless, since a degree of multi-collinearity may still occur with slightly high correlation and could affect confidence intervals for coefficients which tend to become very wide and, hence, affect the t-statistics and the significance levels of variables (Tabachnick and Fidell, 2007), we computed the Variance Inflation Factor (VIF) for all variables. This helps to further check whether multi-collinearity was an issue and if so whether or not it was severe. Chatterjee and Price (1991) argue that VIFs in excess of 10 are symptomatic of multicollinearity problem. However, we recorded the highest VIF of 2.44 for our models, suggesting no multicollinearity problem.

$$
[<<<<\text { Table } 4 \text { about here }>>>>]
$$

\subsection{Regression Results}

Tables 4, 5 and 6 present our regression results. We ran several variations of our main model using the robust standard error to ensure rigour and reliability of our findings. With these results we were able to test our hypothesis and our expectations of the control variables.

\subsubsection{Community expectation and CCID.}

We examined the relationship between community expectation and CCID. We test this relationship using both the one-year lag community news (LnCOMNEWS $\mathrm{t}_{\mathrm{t}-1}$ ) variable and the contemporaneous relationship between them. Model 1 in Table 4 presents the result of the regression with the contemporaneous measure of community news, LnCOMNEWS, as the independent variable of concern. The results (coeff 0.64; t-stat 4.32) show that there is a significant positive relationship, at $1 \%$ level, between the volume of CCID and community expectations, proxy by LnCOMNEWS. This supports our hypothesis of a positive relationship between community expectations and corporate community disclosure. This seems to indicate that firms respond to increased community expectation through increased corporate community involvement disclosures.

However, to explore the relationship between CCID and community expectation further, and recognising the lag in the response by firms to community expectations, we introduced a lag in the model. Thus model 2 in Table 4 presents the result of this relationship. The result (coeff, 0.28; t-stat, 1.99), is generally similar to model 1 in terms of a significant positive relationship although at $5 \%$ level and a lower co-efficient value compared to model 1 . The result reinforces our conjecture that firms respond to legitimacy gap with the society through increased community related disclosure. Models 3 and 4 are slightly different from models 1 and 2 because they include other CSR 
disclosures as additional independent variable. We included this variable to explore the impact of other CSR disclosures that firms make on the relationship between CCID and community expectations. The inclusion of this variable did not change the relationship between our main variables of concern in any significant way, although the coefficients dropped/(improved) in magnitude in model 3/(model 4) respectively. Consequently, these findings seem to support our hypothesis of a significant positive relationship between CCID and community expectations.

From the media agenda-setting theory perspective, one plausible explanation for these findings is that CCID in annual reports might have been influenced by print media coverage on community issues. This could also imply that management responds positively to the expectations of their community stakeholders and these responses are reflected in their disclosure in the annual reports. The findings support the perception that firms target their voluntary disclosures and make additional disclosure only on its merits and to address their legitimacy gaps, in this case, community expectations. The findings also support the argument that firms consider corporate disclosure as a strategic tool. Bebbington et al., (2008) note that firms consider additional disclosure based on their importance. However, as noted in section 2.3.1, our study, using media agenda setting, explores a salient dimension in the intricate multiple dimensional relationships between the corporation, the community and the media. It is therefore quite possible that the corporation could in turn influence the content, action and behaviour of the media.

\subsubsection{CCID and corporate governance (CG) variables.}

We also examined the relationship between CCID and CG (board size, board meeting and board independence respectively) variables in the study. We anticipate a significant positive relationship between these variables and CCID. The results from model 1 in Table 4 show a positive relationship between CCID and board size but this is not statistically significant at the conventional levels. This is similar to the results in models 2, 3, and 4 in Table 4 . The results suggest that board size is inconsequential in CCID. Previous studies have reported inconclusive results regarding the role of board size in corporate voluntary disclosures. The lack of significant relationship between board size and CCID is consistent with the argument of Song and Windram, (2004), and Yermack, (1996) that large board size could be counterproductive, and the lack of statistical significant relationship reported supports the argument that board size does not impact firms' activities, in this instance, corporate voluntary disclosure.

Furthermore, we controlled for board meeting frequency. Overall, the results in models 1-4 of Table 4 show a consistent significant positive relationship between board meeting frequency and CCID. This means that increase in CCID is associated with increase in board meeting frequency. However, the relationship is only statistically significant at $10 \%$ level in models 1 and 2 and insignificant in models 3 and 4 . These findings highlight the inconclusive results that characterise several CG variables.

Consistent with our expectations, the results in models 1-4 in Table 4 show a consistent and significant positive relationship between board independence and CCID at $1 \%$ and 5\% levels. These results indicate that increase in the number of non-executive directors relative to executive directors on the board is associated with increased CCID. The result supports the conjecture that nonexecutive directors represent the interest of the firms' stakeholders including the community of operation and this is consistent with the findings in Yekini et al., (2015) where they argued that nonexecutive directors represent wider interests on the board. The result is also consistent with the argument that non-executive directors are keen to protect their human capital worth and this can be enhanced through increased communication with a firm's community of operation. The positive relationship is also consistent with reported findings in Webb (2004) and Ajinkya, et al., (2005). 


\subsubsection{CCID and CG board level committees.}

We examined the relationship between the presence of a number of board level committees such as risk management, disclosure and CSR committees on CCID as control variables. We anticipated a positive relationship between these committees and CCID but our results in models 14 in Table 4 show a negative relationship. Furthermore, only disclosure committee shows statistically significant relationship with CCID at $1 \%$ level. A possible explanation for these results is that the committees are probably concerned more about the remits of their respective committees' responsibilities which may preclude CCI. The risk management and CSR committees would be concerned about risk management and its communication and expectedly, the CSR committee may focus more on the broad themes rather than a more specific issue such as CCI. The disclosure committee on the other hand will most likely have a broad remit on all disclosures and increased attention on mandatory and other voluntary disclosures which may preclude attention of the committee in respect of CCID.

\subsubsection{CCID and firm specific variables.}

We controlled for four firm specific characteristics (size, performance, leverage and age) in the study. The regression results in models 1-4 presented in Table 4 show that, consistent with our expectations, there is a significant positive relationship between firm size and the volume of CCID. This is significant at 1\% level and supports the findings in studies such as Ho and Wong (2001) and Campbell et al., (2006). Larger firms seem to have higher visibility and higher social pressure for disclosure compared to small sized companies.

The results in models 1-4 of Table 4 do not support our expectation of a positive relationship between firm performance and the volume of CCID. The results show a persistent negative but statistically insignificant relationship between firm performance and CCID, except in model 1 . Previous studies have expressed concerns over the inconclusive nature of the relationship between firm performance and corporate disclosure variables in general. The insignificant CCID/ROE relationship in our study is consistent with findings from Hackston and Milne (1996); Ho and Wong (2001); Hasseldine et al., (2005); while other studies like Haniffa and Cooke (2002) document a statistically significant relationship.

Furthermore, we examine the relationship between leverage and the volume of CCID. In contrast to our expectation, the results in Table 4 show a persistent and significant negative relationship between firm leverage and the volume of CCID. This indicates that highly leveraged firms disclose less CCI compared to less leveraged firms. A possible explanation for the negative relationship is that creditors may be less concerned about CCIDs, which are not the core financial performance issue of primary importance to them. The result may also indicate that highly leveraged firms take strategic disclosure decisions, thereby making less CCIDs and focusing on other disclosures that may be of more concerns to their creditors. The relationship is significant at $1 \%$ and 5\% levels. Finally, our results in model 1-4 in Table 4 seem to support our expectations of a positive relationship between the listing age of a firm and the volume of CCIDs. This indicates that older firms are more likely to make CCIDs than younger firms.

\subsubsection{CCID and other CSR disclosures.}

Consistent with our expectations, our results in models 3 and 4 in Table 4 show a significant positive relationship at $1 \%$ level, with a coefficient of 0.51 and 0.52 respectively, between the volume of CCID and other CSR disclosure. This implies that as disclosures of other CSR information increased in annual reports, information on CCI also increased which confirms our conjecture that CCID might have been motivated by the pressure on firms to disclose more social 
responsibility information in their annual reports (Toms, 2002; Hasseldine et al., 2005; Bebbington et al., 2008).

\subsection{Additional Analysis}

We subject our main findings in Table 4 to several robustness checks and additional analysis to enhance the reliability and rigour of our investigation; we present these below.

\subsubsection{Endogeneity check.}

First, previous studies (Hermalin and Weisbach, 2003; Ajinkya et al., 2005) cautioned on the susceptibility of CG research to endogeneity concerns. Empirical analyses invested with endogeneity problem report spurious regression results and lead to acceptance of hypotheses that should be rejected and vice versa (Garcia-Castro et al., 2010). Endogeneity problem may arise due to feedback effect (simultaneity) or measurement error in the variables. Previous studies (e.g. Garcia-Castro et al., 2010) suggest the use of instrumental variables approach to check and fix this problem. However, identifying a suitable instrumental variable remains a formidable empirical challenge (Hermalin and Weisbach, 2003; Garcia-Castro et al., 2010). In this study, we suspect that other CSR disclosure could be endogenous and therefore correlated with the error terms in our main regression. This violates the Gauss Markov theorem and the regression result will be spurious if this is the case (Garcia-Castro et al., 2010). Greene (2008) provides an intuitive approach to testing for endogeneity, which involves two-stage regression processes that we followed in this study.

In the first stage, the suspected endogenous variable is regressed on the instrumental variable and other exogenous variables in the model. We obtained the residual from this regression and used it in the second stage regression as an independent variable in addition to all other exogenous variables. The coefficient of the instrumental variable should be significant in the first stage regression and the predicted value of the residual (vhat) should not be significant in the second stage regression to rule out endogeneity problem. We used the rank of other CSR disclosure as our instrumental variable. Whilst this is likely to be correlated with other CSR disclosure, it is unlikely to be correlated with our dependent variable and the error terms in the main regression. Models 5 and 6 in Table 5 present the results of this test. Rank is significant in the first stage regression and vhat is insignificant in the second stage regression, confirming the absence of endogeneity in our investigation and thereby reinforcing the findings reported in Table 4.

$[<<<<$ Table 5 about here $>>>>]$

\subsubsection{The effects of the financial crisis period}

In addition to the analyses above, we explored the effects of the financial crisis period on the volume of CCID disclosures. We partitioned our sample in several ways to tease out the various effects of the period on our investigation (Shleifer and Vishny, 2010; Campello et al., 2010; Atkinson et al., 2013). Table 6 presents the results for the various time periods.

$[<<<<$ Table 6 about here $>>>>]$ 
Models $7 \mathrm{a}$ and $7 \mathrm{~b}$ represent the regression results for the period before the crisis without lag and models 7c and 7d include a year lag. The results show positive relationships, although only marginal for models $7 \mathrm{a}$ and $7 \mathrm{c}$ and no significance for models $7 \mathrm{~b}$ and $7 \mathrm{~d}$. Models $7 \mathrm{~b}$ and $7 \mathrm{~d}$ assume the crisis period started effectively in 2008. Table 7 presents the fixed effect results for (during and after) the crisis periods. Models 8a and $8 \mathrm{~b}$ represent the crisis period, with and without lag respectively and model $8 \mathrm{c}$ is the regression results - after the financial crisis. We observed a significant positive relationship between the volume of CCID and community expectations before and after the financial crisis. However, there was an insignificant negative relationship during the financial crisis period (2008-2010), and insignificant positive relationship when the period before the financial crisis covered up to 2007. It seems that corporate voluntary disclosure reflects the uncertainty of the period just before and during the financial crisis period whilst disclosure before and after the financial crisis seems to reflect firms' responsiveness to the expectations of the community.

The insignificant relationships shortly before and during the crisis period might suggest that, during these periods, corporations became more pre-occupied with their financial reports, in order to present a good financial outlook to the investors, rather than their CSR reports. Presenting a good financial outlook at such a critical period could help salvage the reputation of the firm than focusing on social disclosure. This seems to be the societal expectation at that time and confirms that firms adopt a strategic approach in responding to societal expectations. The crisis was no doubt a reflection that corporate behaviour fell below societal expectations and could be perceived to have created a legitimacy gap which firms responded to through increased disclosures. Similarly, the significant relationship after the crises might be indicative of increased disclosure of community activities in response to perceived expectation gap between corporate social performance as reported in the annual reports of companies and community expectations. However, overall, our results indicate a significant positive relationship between CCID and community expectations for the entire period of our investigation.

$$
[<<<<\text { Table } 7 \text { about here }>>>>]
$$

\subsection{Other analysis}

We also consider the robustness of our result to alternative specification by changing the measure of firm size, using log of asset and log of total employee in place of market capitalisation, and return on capital employed as profitability measure in place of return on equity for firm performance. Our main results in Table 4 remain consistent and robust to these specifications.

\section{Conclusion}

This study examined the interactions between community expectations and corporate community involvement disclosures (CCID) in the annual reports of a sample of UK listed companies. This is a unique disclosure element in the annual reports of firms which has received little attention in the extant literature. We based our main conjecture on the media agenda-setting theory which suggests that there is a direct correlation between media coverage and issue salience in the public discourse. We argued that the media's coverage of the CG and the financial crises inadvertently created public expectations of the corporations. This difference in expectations and behaviour is tantamount to a gap between the expectations of the conferring publics and firms' 
behaviour, which may threaten corporations' continued legitimacy in the society. Corporations have to respond to the gaps through effective communications with their conferring publics. A veritable medium of such communication is the annual reports of companies which is statutorily required. This study was based on the disclosures in 800 annual reports covering 2003 to 2012.

We measured CCID as the volume of firms' disclosures of their involvements in the 'life' of their communities of operations in the annual reports. Such disclosures have to be clearly stated and specifically related to firms' community activities, sponsorship, granting local community access to firms' resources including staff time and talents. They cover health, arts, education, recreations, amongst others. We based our measurement of community expectations on the media coverage of community issues in the major print and electronic media contained in the Lexis-Nexis Library for the period 2003-2012. Our FE regression model controlled for both CG and firm specific variables. Our empirical investigation involved a number of pre-estimation and post-estimation tests including endogeneity test which together enhanced the reliability of our findings.

Our investigation reports a number of insightful results. We found a statistically significant positive relationship between community expectations and CCID. This result is persistent when expectations were treated contemporaneously and with a one-year lag. These results seem to indicate that firms treat their corporate disclosures strategically and take a conscious and calculated approach to respond to community expectations. The positive relationship between community expectations and CCID seems to show that firms increase corporate disclosure due to higher community expectations. Furthermore, these findings seem to imply that aggravated community expectations, precipitated by the inglorious CG and financial crises elicited increased disclosure by firms and they responded accordingly. This corporate response to aggravated community expectations may reflect the desire of corporations to maintain and retain their societal legitimacy especially during severe uncertainty that pervaded the periods of these crises.

Moreover, we found a consistent and statistically significant negative relationship between firm leverage and CCID. This result is in contrast with some of the notable findings in the literature regarding the nexus between voluntary disclosure and leverage (Mangena and Pike, 2005; Tsamenyi et al., 2007; Garcia-Castro et al., 2010). Expected positive relationship between leverage and voluntary disclosure is based on the perception that creditors prefer additional corporate information to less, and that firms could benefit from reduced costs of capital by making important voluntary disclosure. However, our finding of an inverse relationship between CCID and leverage seems to suggest that the relationship between leverage and voluntary disclosure depends on the importance of such disclosure to the creditors from the perceptions of the firm. Whilst additional CCID may be invaluable to community stakeholders it may be less so to creditors who may give higher preference to voluntary financial information.

Our findings advance the broad CSR theoretical foundation by exploring the role of the media in CCID. In particular, we introduce the media agenda-setting theory to mainstream CCID research. Our findings seem to support the media agenda theoretical expectation that increase in media coverage of an issue aggravates community expectations and firms respond to these perceived expectations through increased corporate disclosure. Our study therefore provides a fresh theoretical perspective to the broad CSR debate and especially the CCI subset of this debate. In addition to this necessary theoretical breadth, our findings have managerial implications. Firstly, a positive relationship between community expectation and CCID highlights the responsiveness of corporations to their community stakeholders over a period of grave uncertainty. This may be crucial to the establishment of a long term sustainable relationship between the firm and its conferring publics. Corporations should respond effectively to their conferring publics because poor communications may create expectation gaps which may worsen overtime. Secondly, media agenda setting argued that irrespective of the potential to self-select media representations by firms, media outlets make strategic decision on news items to feature and how to frame them in their limited 
space. Therefore, management should genuinely engage with their conferring publics which can foster community support and access to community resource.

This study focused mainly on the disclosure in the annual reports and it may be possible that additional insight could be gained if other corporate communication media are explored. Thus, future studies could explore corporate communication such as standalone CSR report or press releases and earnings announcements. Also the analyses in this study is limited to the impacts of community expectation (through media coverage) on corporate disclosure; an intricate but interesting line of future enquiry could be to explore whether and how corporate disclosure in turn impacts media coverage of community related issues, especially given that the media are also subject to societal legitimacy. Furthermore, this study focused only on the UK FTSE 350 context and although it provides additional information from other context aside the US, it will be useful to explore CCID and the impact of the media in generating community expectation in other jurisdiction with less transparent and free press, such as in developing economies.

\section{Notes}

1. We used the term 'community of operation' to refer broadly to the immediate and remote, physical and non-physical environments in which a firm operates. In other words, it encompasses all the conceivable stakeholders of a firm.

2. Some studies argue that larger board may become dysfunctional and that board decision making may become sluggish due to protracted deliberation and effort loss. Smaller board are suggested to be able to reach decisions faster and compact in operation (Yermack, 1996; Song and Windram, 2004).

3. As with many CG variables, we recognise that other studies such as Eng and Mak (2003) reports negative relationship between board independence and voluntary disclosure and studies such as Ho and Wong (2001) do not find any relationship at all between board independence and voluntary disclosure.

4. Our inter-coder score was well over the threshold of 0.80

\section{Acknowledgements}

The authors are most grateful to the anonymous reviewers for their constructive and useful comments on the earlier versions of this paper. We are also grateful for the useful comments received from the participant of the 2015 Annual British Accounting and Finance Association (BAFA) conference held at the University of Manchester and for the constructive criticisms and comments received from the participants at the $39^{\text {th }}$ Annual congress of the European Accounting Association (EAA) held $10-13$, May 2016 at Maastricht, Netherland, and at $20^{\text {th }}$ Annual conference of the Financial Reporting and Business Communication Special Interest Group of BAFA held in Bristol, UK, between 30 ${ }^{\text {th }}$ June and 1 July 2016.

This research did not receive any specific grant from funding agencies in the public, commercial, or not-for-profit sectors. 


\section{Appendices}

\section{Appendix A: List of UK National and Regional News Papers}

\section{UK NATIONALS:}

Content-Summary: The UK Nationals contains 16 full-text national newspapers distributed throughout the UK. However, only UK National News Papers with relevant articles on CSR and CCI issues, during the period under investigation, are listed below.

$\begin{array}{ll}\text { 1. } & \text { Daily Mail and Mail on Sunday } \\ \text { 2. } & \text { Independent on Sunday } \\ \text { 3. } & \text { Morning Star } \\ \text { 4. } & \text { The Business } \\ \text { 5. } & \text { The Daily Telegraph (London) } \\ \text { 6. } & \text { The Express } \\ \text { 7. } & \text { The Guardian (London) }\end{array}$

8. The Independent (London)

9. The Observer

10. The Sunday Express

11. The Sunday Telegraph (London)

12. The Sunday Times (London)

13. The Times (London)

\section{UK Regional Publications:}

Content-Summary: The UK Regional publications contain all the regional sources published in the UK held by LexisNexis. However, only UK Regional publications with relevant articles on CSR and CCI issues, during the period under investigation are listed below:

$\begin{array}{ll}\text { 1. } & \text { Aberdeen Evening Express } \\ \text { 2. } & \text { Aberdeen Press \& Journal } \\ \text { 3. } & \text { Bath Chronicle } \\ \text { 4. } & \text { Belfast News Letter } \\ \text { 5. } & \text { Berwick Advertiser } \\ \text { 6. } & \text { Belfast Telegraph } \\ \text { 7. } & \text { Birmingham Evening Mail } \\ \text { 8. } & \text { Birmingham Post } \\ \text { 9. } & \text { Bristol Evening Post } \\ \text { 10. } & \text { Business and Finance } \\ \text { 11. } & \text { Carmarthen Journal } \\ \text { 12. } & \text { Chester Chronicle } \\ \text { 13. } & \text { Cornish Guardian } \\ \text { 14. } & \text { Coventry Evening Telegraph } \\ \text { 15. } & \text { Croydon Advertiser }\end{array}$
16. Daily Post (Liverpool)
17. Daily Record
18. Derby Evening Telegraph
19. Evening Chronicle (Newcastle)
20. Evening Gazette
21. Evening Herald (Plymouth)
22. Evening News (Edinburgh)
23. Evening Times (Glasgow)
24. Express \& Echo (Exeter)
25. Fife Free Press
26. Fosse Way Magazine
27. Gloucestershire Echo
28. Grimsby Evening Telegraph
29. Hertfordshire Mercury
30. Huddersfield Daily Examiner

UK Regional Publications Cont'd:

$\begin{array}{ll}\text { 31. } & \text { Hull Daily Mail } \\ \text { 32. } & \text { Irish News } \\ \text { 33. } & \text { Kent and Sussex Courier } \\ \text { 34. } & \text { Kidderminster Shuttle } \\ \text { 35. } & \text { Leicester Mercury } \\ \text { 36. } & \text { Liverpool Daily Echo } \\ \text { 37. } & \text { Loughborough Echo } \\ \text { 38. } & \text { Manchester Evening News } \\ \text { 39. } & \text { Melton Times } \\ \text { 40. } & \text { Metro (UK) } \\ \text { 41. } & \text { Mid Devon Gazette } \\ \text { 42. } & \text { Middlesbrough Evening Gazette } \\ 43 . & \text { North Devon Journal } \\ 44 . & \text { Nottingham Evening Post } \\ 45 . & \text { Peterborough Evening Telegraph } \\ 46 . & \text { Retford Times series } \\ 47 . & \text { Scarborough Evening News } \\ 48 . & \text { Scotland on Sunday } \\ 49 . & \text { Scunthorpe Evening Telegraph } \\ 50 . & \text { South Wales Echo } \\ 51 . & \text { South Wales Evening Post } \\ 52 . & \text { Southern Reporter } \\ 53 . & \text { Sunday Business } \\ 54 . & \text { The Cornishman } \\ 55 . & \text { The Evening Standard (London) } \\ 56 . & \text { The Gloucester Citizen } \\ & \\ & \end{array}$

57. The Herald (Glasgow)

58. The Independent - Business \& Money

59. The Journal (Newcastle, UK)

60. The Northern Echo

61. The Scotsman

62. The Sentinel (Stoke)

63. The Sunday Herald

64. The Sunderland Echo

65. The Times Educational Supplement

66. The Times Higher Education Supplement

67. The Warsaw Voice

68. The West Briton

69. The Western Mail

70. This is Brighton \& Hove

71. This is Essex

72. This is Hampshire

73. This is Local London

74. This is NorthEast

75. Watford Observer

76. Western Daily Press

77. Western Gazette series

78. Western Morning News (Plymouth)

79. Western People

80. Yeovil Express

81. Yorkshire Evening Post

82. Yorkshire Post 


\section{Appendix B: Hausman Test}

. hausman fixed random

\begin{tabular}{|c|c|c|c|c|}
\hline & \multicolumn{2}{|c|}{ Coefficients -} & \multirow[b]{2}{*}{$\begin{array}{c}(b-B) \\
\text { Difference }\end{array}$} & \multirow[b]{2}{*}{$\begin{array}{c}\operatorname{sqrt}\left(\operatorname{diag}\left(V_{-} b-V_{-} B\right)\right. \\
\text { S.E. }\end{array}$} \\
\hline & $\begin{array}{c}\text { (b) } \\
\text { fixed }\end{array}$ & $\begin{array}{c}(B) \\
\text { random }\end{array}$ & & \\
\hline laglncomnews & -.2905461 & .0568203 & -.3473665 & .0401424 \\
\hline bm & .0386875 & .0476217 & - . 0089342 & .0071939 \\
\hline $\mathrm{bc}$ & 1.359539 & 1.77731 & -.4177712 & .2734209 \\
\hline bs & -.008624 & -.0222605 & .0136365 & .0182572 \\
\hline rc & - . . 0983218 & .0652503 & -.1635722 & $.10000 \odot 7$ \\
\hline $\mathrm{dc}$ & -.799401 & -.4204397 & -.3789613 & .0714062 \\
\hline $\operatorname{csrc}$ & -.1553255 & .0501385 & -.205464 & .0704178 \\
\hline lnocsr & .516178 & .689335 & -.1731569 & .0265886 \\
\hline Inmv & .3588276 & .2857775 & .0730501 & .0318669 \\
\hline roe & -.0030124 & .0050462 & - . .0๑80586 & .0011857 \\
\hline lev & $-.0 \odot 94771$ & $-.0 \odot 46601$ & - . .0๑4817 & .0016834 \\
\hline age & .1689744 & - . . 0010697 & .1700442 & .0250013 \\
\hline
\end{tabular}

$\mathrm{b}=$ consistent under $\mathrm{Ho}$ and $\mathrm{Ha}$; obtained from $\mathrm{xtreg}$ $\mathrm{B}=$ inconsistent under $\mathrm{Ha}$, efficient under $\mathrm{Ho}$; obtained from xtreg

Test: Ho: difference in coefficients not systematic

$$
\begin{aligned}
& \operatorname{chi2}(12)=(b-B)^{\prime}\left[\left(V \_b-V \_B\right)^{\wedge}(-1)\right](b-B) \\
& =\quad 72.11 \\
& \text { Prob }>\text { chi2 }=0.0000 \\
& \text { ( } V \_b-V \_B \text { is not positive definite) }
\end{aligned}
$$




\section{References}

Adams, C. A., Hill, W., Roberts, C. B., Carol, A. A., Wan-Ying, H., and Clare, B. R. (1998). Corporate Social Reporting Practices in Western Europe: Legitimating Corporate Behaviour? British Accounting Review, 30(1), 1-21.

Adegbite, E. and Nakajima, C. (2011). Corporate governance and responsibility in Nigeria. International Journal of Disclosure and Governance 8(3): 252-271.

Ader, C. R. (1995). A longitudinal study of agenda setting for the issue of environmental pollution. Journalism and Mass Communication Quarterly, 72(2), 300-311.

Aerts, W., and Cormier, D. (2009). Media legitimacy and corporate environmental communication. Accounting, organizations and society, 34(1), 1-27.

Ajinkya, B., Bhojraj, S., and Sengupta, P. (2005). The Association between Outside Directors , Institutional Investors and the Properties of Management Earnings Forecasts. Journal of Accounting Research, 43(3), 343-376.

Amaeshi, K., Adegbite, E. \& Rajwani, T. (2016) Corporate social responsibility in challenging and non-enabling institutional contexts: Do institutional voids matter? Journal of Business Ethics, 2016, 134, (1): 135-153

Atkinson, T., Luttrell, D. and Rosenblum, H. (2013) How Bad Was It? The Costs and Consequences of the 2007-2009 Financial Crisis. Staff Papers published by the Federal Reserve Bank of Dallas. No. 20. July 2013 https://dallasfed.org/assets/documents/research/staff/staff1301.pdf Accessed 15-01-16.

Bachmann, P and Ingenhoff, D, (2016) Legitimacy through CSR disclosures? The advantage outweighs the disadvantages, Public Relations Review, 42(3), 386-394.

Basu, K., and Palazzo, G. (2008). Corporate social responsibility: A process model of sensemaking. Academy of management review, 33(1), 122-136.

Beattie, V., McInnes, B., and Fearnley, S. (2004). A methodology for analysing and evaluating narratives in annual reports: a comprehensive descriptive profile and metrics for disclosure quality attributes, Accounting Forum, 28(3), 205-239

Beatty, A. and Liao, S. (2013), "Why do US multinational's voluntary geographical employment disclosures tell us?”, Paper presented at the Harvard/JAE Corporate Accountability Reporting Conference, Boston, MA, January.

Bebbington, J., Larrinaga-González, C., and Moneva-Abadía, J. M. (2008). Corporate social reporting and reputation risk management. Accounting, Auditing and Accountability Journal, 21(3), 337-361.

Beretta, S., and S. Bozzolan. (2008) Quality versus quantity: The case of forward-looking disclosure. Journal of Accounting, Auditing and Finance 23(3), 333-375

Botosan, C. A., (2004) Discussion of a framework for the analysis of firm risk communication. The International Journal of Accounting, 39(3), 289-295.

Brants, K., and De Haan, Y. (2010). Taking the public seriously: three models of responsiveness in media and journalism. Media, culture, and society, 32(3), 411. 
Brown, D.L., Guidry, R.P. and Patten, D.M. (2009), "Sustainability reporting and perceptions of corporate reputation: an analysis using Fortune most admired scores”, Advances in Environmental Accounting and Management, 4, 83-104.

Brown, N., and Deegan, C. (1998). The public disclosure of environmental performance information-a dual test of media agenda setting theory and legitimacy theory. Accounting and business research, 29(1), 21-41.

Bryman, A. and Bell, E., (2007), Business Research Methods, (2nd Ed) Oxford: Oxford University Press

Campbell, D. J., (2000), Legitimacy theory or managerial reality construction? Corporate social disclosure in Marks and Spencer Plc corporate reports, 1969-1997. Accounting Forum, 24(1), 80-100

Campbell, D. J., Moore, G., Shrives, P., Geoff, M., Philip, S., and David, C. (2006). Cross-sectional effects in community disclosure. Accounting, Auditing and Accountability Journal, 19(1), 96114.

Campello, M., Graham J R and C. R. Harvey (2010). The real effects of financial constraints: Evidence from a financial crisis. Journal of Financial Economics, 97(2010), 470-487

Carroll, A. B. (1991). The pyramid of corporate social responsibility: Toward the moral management of organizational stakeholders. Business Horizons 34(4), 39-48.

Chatterjee and Price (1991). Regression Analysis by Example. 2nd Edition, John Wiley and Sons, New York,

Cohen, B (1963). The press and foreign policy. New York: Harcourt.

Cormier, D., Ledoux, M.-J. M.-J., Magnan, M., and Aerts, W. (2010). Corporate governance and information asymmetry between managers and investors. Corporate Governance, 10(5), 574589.

Coupland, C., (2006). Corporate social and environmental responsibility in web-based reports: Currency in the banking sector? Critical perspectives on accounting, 17(7), 865-881.

Dearing, J. W., and E. M. Roger. (1996). Agenda Setting. Thousand Oaks, CA: Sage.

Deegan, C. (2002). The legitimising effect of social and environmental disclosures - a theoretical foundation. Accounting, Auditing and Accountability Journal, 15(3), 282-311.

Deegan, C., and Gordon, B. (1996). A Study of the Environmental Disclosure Practices of Australian Corporations. Accounting and Business Research, 26(3), 187-199.

Deegan, C., Rankin, M., and Tobin, J. (2002). An examination of the corporate social and environmental disclosures of BHP from 1983-1997: A test of legitimacy theory. Accounting, Auditing and Accountability Journal, 15(3), 312-343.

Deegan, C., Rankin, M., and Voght, P. (2000). Feature article Firms ' disclosure reactions to major social incidents : Australian evidence. Accounting Forum, 24(1), 101-30

Dhaliwal, D.S., Li, O.Z., Tsang, A. and Yang, G.Y. (2011), "Voluntary nonfinancial disclosure and the cost of equity capital: the initiation of corporate social responsibility reporting”, The Accounting Review, 86 (1), 59-100. 
Elo, S., and Kyngäs, H. (2008). The qualitative content analysis process Journal of advanced nursing, 62(1), 107-115.

Elzahar, H., and Hussainey, K. (2012). Determinants of narrative risk disclosures in UK interim reports. The Journal of Risk Finance, 13(2), 133-147.

Eng, L. L. and Mak, Y. T. (2003) Corporate governance and voluntary disclosure, Journal of Accounting and Public Policy, 22: 325-346.

Entman, R. M. (1989). How the media affect what people think: An information processing approach. The journal of Politics, 51(02), 347-370.

Evans, J., Evans, R. and Loh, S., (2002). Corporate Governance and Declining Firm Performance. International Journal of Business Studies, 10(1), 1-18

Fang, L., and Peress, J. (2009). Media coverage and the cross-section of stock returns. The Journal of Finance, 64(5), 2023-2052.

Freedman, M., and Stagliano, a. J. (2008). Accounting Disclosures of Toxics Release Inventory for 2002. Accounting and the Public Interest, 8(1), 21-38.

Gans, H. (1979). Deciding what's news. New York: Pantheon Books

Garcia-Castro, R., Ariño, M. A., and Canela, M. A. (2010). Does Social Performance Really Lead to Financial Performance? Accounting for Endogeneity. Journal of Business Ethics, 92(1), 107126.

Garcia-Sanchez, I. M., Cuadrado-Ballesteros, B., and Sepulveda, C. (2014). Does media pressure moderate CSR disclosures by external directors? Management Decision, 52(6), 1014-1045.

Gilchrist, A. (2003). Community Development in the UK--Possibilities and Paradoxes. Community Development Journal, 38(1), pp.16-25.

Gray, R., Kouhy, R. and Lavers, S. (1995). Methodological themes: Constructing a research database of social and environmental reporting by UK companies. Accounting, Auditing and Accountability Journal, 8(2), 78-101.

Greene, W. H., (2008). Econometric Analysis, 6th Edition Upper Saddle River, N.J. Prentice Hall

Guthrie, J., Johanson, U., Bukh, P.N. and Sánchez, P. (2003). Intangibles and the transparent enterprise: New strands of knowledge. Journal of Intellectual Capital, 4(4), 429-440

Guthrie, J., Petty, R., Yongvanich, K., and Ricceri, F. (2004). Using content analysis as a research method to inquire into intellectual capital reporting. Journal of Intellectual Capital, 5(2), 282293.

Hackston, D., and Milne, M. J. (1996). Some determinants of social and environmental disclosures in New Zealand companies. Accounting, Auditing and Accountability Journal, 9(1), 77-108.

Halme, M., and Laurila, J. (2009). Philanthropy, integration or innovation? Exploring the financial and societal outcomes of different types of corporate responsibility. Journal of business ethics, 84(3), 325-339.

Haniffa, R. M., and Cooke, T. E. (2002). Culture, Corporate Governance and Disclosure in Malaysian Corporations. Abacus, 38(3), 317-349. 
Hasseldine, J., Salama, A. I. I., and Toms, J. S. S. (2005). Quantity versus quality: the impact of environmental disclosures on the reputations of UK Plcs. The British Accounting Review, 37(2), 231-248.

Healy, P. and Serafeim, G. (2013), “Causes and consequences of firms' self-reported anticorruption efforts”, Paper presented at the Harvard/JAE Corporate Accountability Reporting Conference, Boston, MA, January.

Hermalin, B.E. and Weisbach, M.S., (2003). Boards of directors as an endogenously determined institution: A survey of the economic literature. FRBN Economic Review (April, 2003) http://faculty.haas.berkeley.edu/hermalin/601herma.pdf Accessed 15-01-16.

Ho, S. S. M., and Wong, K. S. (2001). A study of the relationship between corporate governance structures and the extent of voluntary disclosure, Journal of International Accounting Auditing and Taxation, 10, 139-156.

Hooghiemstra, R. 2000. Corporate communication and impression management. New perspectives why companies engage in social reporting. Journal of Business Ethics 27, 55-68.

Hooks, J., and van Staden, C. J. (2011). Evaluating environmental disclosures: The relationship between quality and extent measures. The British Accounting Review, 43(3), 200-213.

Ingram, R. W., and Frazier, K. B. (1980). Environmental Performance and Corporate Disclosure. Journal of Accounting Research, 18(2), 614-622.

Islam, M. A., and Deegan, C. (2010). Media pressures and corporate disclosure of social responsibility performance information: a study of two global clothing and sports retail companies. Accounting and Business Research, 40(2), 131-148.

Jenkins, H. and Yakovleva, N., (2006). Corporate social responsibility in the mining industry: Exploring trends in social and environmental disclosure. Journal of cleaner production, 14(3), 271-284.

Jizi, M. I., Salama, A., Dixon, R., and Stratling, R. (2014). Corporate governance and corporate social responsibility disclosure: evidence from the US banking sector. Journal of Business Ethics, 125(4), 601-615.

Karamanou and Vafeas (2005). The Association between Corporate Boards, Audit Committees and Management Earnings Forecasts: An Empirical Analysis. Journal of Accounting Research, 43(3): 453-486

Korthagen, I., (2015). Who Gets on the News? The relation between media biases and different actors in news reporting on complex policy processes. Public Management Review, 17(5), pp.617-642.

Krippendorff, K., (2004) 'Content Analysis: An Introduction to its Methodology', (2nd Ed). Thousand Oak, London: Sage

Li, J., Pike, R., and Haniffa, R. (2008). Intellectual capital disclosure and corporate governance structure in UK firms. Accounting and Business Research, 38(2), 137-159.

Mangena, M., and Pike, R. (2005). The effect of audit committee shareholding, financial expertise and size on interim financial disclosures. Accounting and Business Research, 35(4), 327-349.

McCombs, M and Shaw, D (1972). The agenda-setting function of mass media. Public Opinion Quarterly 36 (2), 176-187 
McCombs, M. (2000).The Agenda Setting Role of Mass Communication: Mass Media and Public Opinion. Egyptian Journal of Public Opinion Research 1(2) 1-3 and 1(3) 83-84

McCombs, M. E., Shaw, D. L., and Weaver, D. H. (2014). New directions in agenda-setting theory and research. Mass Communication and Society, 17(6), 781-802.

McWilliams, A., and Siegel, D. (2001). Corporate social responsibility: A theory of the firm perspective. Academy of management review, 26(1), 117-127.

Milne, M. J., and Adler, R. W. (1999). Exploring the reliability of social and environmental disclosures content analysis. Accounting, Auditing and Accountability Journal, 12(2), 237256.

Moon, J., and Muthuri, J. N. (2006). An evaluation of Corporate Community Investment in the UK Current developments , future challenges. A report of Charities Aid Foundation, United Kingdom (pp. 1-24).

Morsing, M., Schultz, M., and Nielsen, K. U. (2008). The 'Catch 22' of communicating CSR: findings from a Danish study. Journal of Marketing Communications, 14(2), 97-111.

Nerlich, B., and Halliday, C. (2007). Avian flu: the creation of expectations in the interplay between science and the media. Sociology of health \& illness, 29(1), 46-65.

O’Donovan, G. (1999). Managing legitimacy through increased corporate environmental reporting: an exploratory study. Interdisciplinary Environmental Review, 1(1), 63-99

Patten, D.M. (2012), "White tigers, zoos, and sustainability reporting: a cynical reflection”, Social and Environmental Accountability Journal, 32(1), 17-25.

Patten, D.M. (2013), "Lessons from the third wave: a reflection on the rediscovery of corporate social responsibility by the mainstream accounting research community”, Financial Reporting, 2(2), 9-26.

Patten, D.M. and Zhao, N. (2014), “Standalone CSR reporting by US retail companies”, Accounting Forum, 38(2), 132-144.

Peloza, J., and Falkenberg, L. (2009). The role of collaboration in achieving corporate social responsibility objectives. California Management Review, 51(3), 95-113.

Rehbein, K., and Schuler, D. A. (2015). Linking Corporate Community Programs and Political Strategies a Resource-Based View. Business \& Society, 54(6), 794-821.

Scheufele, D.A. and Tewksbury, D., (2007). Framing, agenda setting, and priming: The evolution of three media effects models. Journal of communication, 57(1), pp.9-20.

Shleifer A. A. and Vishny, R. W. (2010). Unstablebanking Banking. Journal of Financial Economics 97 (2010) 306-318

Song, J., and Windram, B. (2004). Benchmarking Audit Committee Effectiveness in Financial Reporting. International Journal of Auditing, 8(3), 195-205.

Suchman, M. C. (1995). Managing legitimacy: Strategic and institutional approaches. Academy of management review, 20(3), 571-610.

Tabachnick, B.G. and Fidell, L.S., (2007). Using Multivariate Statistics, (5th Ed), Pearson Education, Inc. Boston, MA 
Thorne, L., S. Mahoney, L. and Manetti, G., (2014). Motivations for issuing standalone CSR reports: a survey of Canadian firms. Accounting, Auditing \& Accountability Journal, 27(4), 686-714.

Toms, J.S., (2002). Firm resources, quality signals and the determinants of corporate environmental reputation: some UK evidence. British Accounting Review 34(3), 257-282.

Tsamenyi, M., Enninful-Adu, E., and Onumah, J. (2007). Disclosure and corporate governance in developing countries: evidence from Ghana. Managerial Auditing Journal, 22(3), 319-334.

van der Wurff, R., and Schönbach, K. (2014). Audience expectations of media accountability in the Netherlands. Journalism Studies, 15(2), 121-137.

Vickers, A J, (2005). Parametric versus non-parametric statistics in the analysis of randomized trials with non-normally distributed data. BMC Medical Research Methodology, 5(35).

Wanta, W., Golan, G., and Lee, C. (2004). Agenda setting and international news: Media influence on public perceptions of foreign nations. Journalism \& Mass Communication Quarterly, 81(2), 364-377.

Watson, A. Shrives, P and Marston, C. (2002). Voluntary Disclosure of Accounting Ratios in the UK. British Accounting Review 34(4), 289-313

Weaver, D. H., Graber, D. A., McCombs, M. E., and Eyal, C. H. (1981). Media agenda-setting in a presidential election. New York: Praeger.

Webb, E. (2004). An Examination of Socially Responsible Firms’ Board Structure. Journal of Management and Government, 8, 255-277.

Wilson, M. and Lombardi, R. (2001) Globalization and its Discontents, Ivey Business Journal, 66, 69-72.

Yekini, K., Adelopo, I., Androkopolous, P. and Yekini, S., (2015) Impact of board independence on the quality of community disclosures in annual reports. Accounting Forum 39(4), 249-267

Yekini, K., and Jallow, K. (2012). Corporate community involvement disclosures in annual report: A measure of corporate community development or a signal of CSR observance? Sustainability Accounting, Management and Policy Journal, 3(1), 7-32.

Yermack, D. (1996). Higher market valuation of companies with a small board of directors. Journal of Financial Economics, 40(2), 185-211. 


\section{Table 1: Definition of variables:}

\begin{tabular}{|c|c|}
\hline Variables & Definitions \\
\hline CCID & Volume of CCID based on word count \\
\hline COMNEWS & Media coverage on community issues (word count) \\
\hline BODMET & Defined as the number of board meetings in a year. \\
\hline BODCOMP & $\begin{array}{l}\text { Defined as the proportion of total independent non-executive directors to total } \\
\text { directors on the board. }\end{array}$ \\
\hline BODSIZ & Defined as the total number of directors on the board \\
\hline RISKCOM & $\begin{array}{l}\text { Standalone Risk committee, measured as dichotomous variable where } 1=\text { Presence } \\
\text { of Risk committee and } 0=\text { otherwise }\end{array}$ \\
\hline DISCOM & $\begin{array}{l}\text { Disclosure committee, measured as dichotomous variable where } 1=\text { Presence of a } \\
\text { disclosure committee and } 0=\text { otherwise }\end{array}$ \\
\hline CSRCOM & $\begin{array}{l}\text { CSR committee, measured as dichotomous variable where } 1=\text { Presence of CSR } \\
\text { committee and } 0=\text { otherwise }\end{array}$ \\
\hline OTHCSRD & Word count of other CSR disclosures e.g. environmental, human resources etc. \\
\hline MCAP & $\begin{array}{l}\text { Market capitalisation: measures firm size and is obtained from DataStream with } \\
\text { mnemonic code MV }\end{array}$ \\
\hline ROE & $\begin{array}{l}\text { Return on Equity: measures the financial performance of firms and is obtained from } \\
\text { DataStream with mnemonic code (WC08301) }\end{array}$ \\
\hline LEV & $\begin{array}{l}\text { Defines the gearing ratio - the corporations' exposure to short and long term risk and } \\
\text { is measured by the ratio of total debt to total capital. (WC08221) }\end{array}$ \\
\hline AGE & Listing age \\
\hline
\end{tabular}

*All data were sourced from company’s annual reports, Thompson Reuter DataStream and Lexis Library. 
Table 2: Descriptive Statistics

\begin{tabular}{|lllll|}
\hline Variables & Mean & Std Dev & Min & Max \\
\hline & & & & \\
CCID & 476.11 & 496.41 & 0 & 3271 \\
COMNEWS & 7310 & 2658 & 3629 & 12844 \\
BODMET & 8.348 & 2.647 & 3 & 16 \\
BODCOMP & 0.623 & 0.137 & 0 & 0.93 \\
BODSIZ & 10.19 & 2.896 & 5 & 18 \\
CSRCOM & 0.333 & 0.471 & 0 & 1 \\
DISCOM & 0.220 & 0.415 & 0 & 1 \\
RISKCOM & 0.313 & 0.464 & 0 & 1 \\
OTHCSRD & 1880 & 1547 & 0 & 12400 \\
MCAP (£'m) & 9,024 & $19,639.88$ & 6.955 & $162,838.5$ \\
ROE (\%) & 15.852 & 17.661 & -25.32 & 53.42 \\
LEV (\%) & 39.04 & 25.74 & 0 & 98.8 \\
Age (yrs) & 22.15 & 18.76 & 1 & 66 \\
\hline
\end{tabular}

Table 3: Correlation Matrix of all IVs

\begin{tabular}{|c|c|c|c|c|c|c|c|c|c|c|c|c|}
\hline VAR & 1 & 2 & 3 & 4 & 5 & 6 & 7 & 8 & 9 & 10 & 11 & 12 \\
\hline 1. COMNEWS & 1.000 & & & & & & & & & & & \\
\hline 2. BODMET & 0.118 & 1.000 & & & & & & & & & & \\
\hline 3. ВODCOMP & 0.139 & -0.086 & 1.000 & & & & & & & & & \\
\hline 4. BODSIZ & 0.034 & 0.016 & 0.204 & 1.000 & & & & & & & & \\
\hline 5. CSRCOM & 0.098 & 0.108 & 0.170 & 0.250 & 1.000 & & & & & & & \\
\hline 6. DISCOM & 0.134 & 0.150 & 0.229 & 0.346 & 0.317 & 1.000 & & & & & & \\
\hline 7. RISCOM & 0.069 & 0.057 & 0.064 & 0.064 & 0.074 & 0.176 & 1.000 & & & & & \\
\hline 8. OTHCSRD & 0.295 & 0.222 & 0.173 & 0.273 & 0.317 & 0.288 & 0.106 & 1.000 & & & & \\
\hline 9.MCAP & 0.023 & 0.100 & 0.164 & 0.537 & 0.115 & 0.274 & 0.017 & 0.208 & 1.000 & & & \\
\hline 10. ROE & 0.112 & 0.086 & 0.029 & 0.061 & 0.136 & 0.164 & 0.025 & 0.160 & 0.165 & 1.000 & & \\
\hline 11. LEV & 0.030 & 0.070 & 0.062 & 0.195 & 0.113 & 0.092 & 0.069 & 0.157 & 0.037 & 0.116 & 1.000 & \\
\hline 12. Age (yrs) & 0.081 & 0.096 & 0.037 & 0.209 & 0.114 & 0.123 & 0.101 & 1.273 & 0.226 & 0.117 & 0.217 & 1.000 \\
\hline
\end{tabular}


Table 4: Fixed Effect Regression Results (Dependent variable [DV]: LnCCID)

\begin{tabular}{|c|c|c|c|c|c|}
\hline \multirow[t]{2}{*}{ Variables } & $\begin{array}{c}\text { Model 1 } \\
\text { With } \\
\text { LnCOMNEWS }\end{array}$ & $\begin{array}{c}\text { Model } 2 \\
\text { With 1-year Lag } \\
\text { LnCOMNEWS }\end{array}$ & $\begin{array}{c}\text { Model 3 } \\
\text { With } \\
\text { LnCOMNEWS } \\
\text { \& OTHCSRD } \\
\end{array}$ & $\begin{array}{l}\text { Model } 4 \\
\text { With 1-year Lag } \\
\text { LnCOMNEWS \& } \\
\text { OTHCSRD } \\
\end{array}$ & \multirow[t]{2}{*}{ VIF } \\
\hline & Coeff (t-stat) & Coeff (t-stat) & Coeff (t-stat) & Coeff (t-stat) & \\
\hline $\operatorname{LnCOMNEWS}^{\dagger}$ & $0.640(4.32) * * *$ & $0.279(1.99) * *$ & $0.592(4.17) * * *$ & $0.285(2.15) * *$ & 1.05 \\
\hline BODMET & $0.048(1.85) *$ & $0.043(1.67) *$ & $0.037(1.47)$ & 0.038 (1.53) & 1.10 \\
\hline BODCOMP & $1.573(2.61) * * *$ & $1.837(2.95) * * *$ & $1.302(2.28) * *$ & $1.408(2.38) * *$ & 1.15 \\
\hline BODSIZ & $0.016(0.46)$ & $0.001(0.02)$ & $0.002(0.05)$ & $-0.011(-0.33)$ & 1.71 \\
\hline CSRCOM $^{\mathrm{a}}$ & $-0.072(-0.41)$ & $-0.113(-0.65)$ & $-0.097(-0.58)$ & $-0.155(-0.94)$ & 1.22 \\
\hline DISCOM $^{\mathrm{a}}$ & $\begin{array}{l}-1.046(-5.51) \\
* * *\end{array}$ & $\begin{array}{l}-0.979(-5.09) \\
* * *\end{array}$ & $\begin{array}{l}-0.879(-4.81) \\
* * *\end{array}$ & $\begin{array}{l}-0.804(-4.37) \\
* * *\end{array}$ & 1.40 \\
\hline RISKCOM $^{\mathrm{a}}$ & $-0.273(-1.42)$ & $-0.238(-1.19)$ & $-0.153(-0.83)$ & $-0.106(-0.55)$ & 1.07 \\
\hline LnOTHCSRD $^{\dagger}$ & & & 0.505 (8.18) *** & $0.516(8.46) * * *$ & 1.43 \\
\hline Ln $\mathrm{MCAP}^{\dagger}$ & $0.557(10.27) * * *$ & $0.502(8.33) * * *$ & $0.438(8.12) * * *$ & $0.363(6.09) * * *$ & 2.44 \\
\hline ROE & $-0.014(-2.35) * *$ & $-0.009(-1.48)$ & $-0.009(-1.61)$ & $-0.006(-1.05)$ & 1.09 \\
\hline LEV & $\begin{array}{l}-0.009(-2.59) \\
* * *\end{array}$ & $\begin{array}{l}-0.011(-3.11) \\
* * *\end{array}$ & $-0.008(-2.24) * *$ & $\begin{array}{l}-0.011(-2.91) \\
* * *\end{array}$ & 1.12 \\
\hline AGE & $0.329(14.34) * * *$ & $0.255(10.29) * * *$ & $0.231(9.26) * * *$ & $0.169(6.60) * * *$ & 1.24 \\
\hline Constant & $-1.276(-1.01)$ & $-2.259(-1.74) *$ & $-1.987(-1.64)$ & $-2.633(-2.13) * *$ & \\
\hline Adjusted $R^{2}$ & 0.597 & 0.571 & 0.631 & 0.614 & \\
\hline F test & $14.030 * * *$ & $11.624 * * *$ & $15.915 * * *$ & $13.573 * * *$ & \\
\hline$N$ & 793 & 719 & 793 & 719 & \\
\hline
\end{tabular}

Notes: This table reports the results of our examination of the effect of Community Expectation measured by media coverage on community issues on Community Involvement Disclosures estimated as LnCCIDit $=\alpha_{0}+$ $\beta_{1}$ LnCOMNEWSit $-1_{1}+\beta_{2}$ BODMETit $+\beta_{3}$ BODCOMPit $+\beta_{4}$ BODSIZit $+\beta_{5}$ RISKCOMit $^{2} \beta_{6}$ DISCOMit + $\beta_{7}$ CSRCOMit $+\beta_{8}$ LnOTHCSRDit $+\beta_{9}$ LnMCAPit $+\beta_{10}$ ROEit $+\beta_{11}$ LEVit $+\beta_{12}$ AGEit + Cit

$(\mathrm{p}>0.10)=$ Not Significant

$*(p \leq 0.10)=$ Significant at $10 \%$

$* *(\mathrm{p} \leq 0.05)=$ Significant at $5 \%$

$* * *(\mathrm{p} \leq 0.01)=$ Significant at $1 \%$

${ }^{\mathrm{a}}$ Dichotomous variable where $1=$ presence of and $0=$ absence of.

${ }^{\dagger} \mathrm{Ln}$ stands for Log transformed variables 
Table 5: 2SLS Regression Results

\begin{tabular}{|c|c|c|}
\hline \multirow[t]{2}{*}{ Variables } & $\begin{array}{c}\text { Model } 5 \text { (DV: LnOTHCSRD) } \\
\text { First stage regression } \\
\end{array}$ & $\begin{array}{c}\text { Model } 6 \text { (DV: LnCCID) } \\
\text { Second stage regression }\end{array}$ \\
\hline & Coeff (t-stat) & Coeff (t-stat) \\
\hline \multirow{3}{*}{$\begin{array}{l}\text { 1-yr lag LnCOMNEWS } \\
\text { BODMET } \\
\text { BODCOMP }\end{array}$} & $0.054(-0.73)$ & $0.282(-2.13) * *$ \\
\hline & $0.010(0.75)$ & $0.044(1.80) *$ \\
\hline & $0.549(1.68) *$ & $1.377(2.34) * *$ \\
\hline BODSIZ & $0.008(0.43)$ & $-0.009(-0.28)$ \\
\hline DISCOM $^{\mathrm{a}}$ & $-0.262(-2.61) * * *$ & $-0.811(-4.46) * * *$ \\
\hline RISKCOM $^{\mathrm{a}}$ & $-0.149(-1.42)$ & $-0.109(-0.57)$ \\
\hline LnOTHCSRD $^{\dagger}$ & & $0.513(8.39) * * *$ \\
\hline $\operatorname{LnMCAP}^{\dagger}$ & $0.180(5.61) * * *$ & $0.353(5.96) * * *$ \\
\hline ROE & $-0.002(-1.31)$ & $-0.003(-0.81)$ \\
\hline LEV & $-0.001(-0.46)$ & $-0.010(-2.99) * * *$ \\
\hline AGE & 0.047 (3.15) *** & $0.162(6.42) * * *$ \\
\hline rank & $0.003(15.43) * * *$ & \\
\hline Vhat & & $0.29(1.56)$ \\
\hline & 0.533 & 0.403 \\
\hline \multirow{2}{*}{$\begin{array}{r}\text { Adjusted } R^{2} \text { Within } \\
\text { Between } \\
\text { Overall }\end{array}$} & 0.458 & 0.064 \\
\hline & 0.421 & 0.076 \\
\hline F- test & $65.29 * * *$ & $38.66^{* * *}$ \\
\hline$N$ & 720 & 720 \\
\hline
\end{tabular}

Notes: This table reports the results of the two stage least square regression analysis to test for endogeneity problems; where CCIDit $=\alpha_{0}+\beta_{1}$ COMNEWSit $-1_{1}+\beta_{2}$ BODMETit $+\beta_{3}$ BODCOMPit $+\beta_{4}$ BODSIZit $+\beta_{5}$ RISKCOMit + $\beta_{6}$ DISCOMit $+\beta_{9}$ LnMCAPit $+\beta_{10}$ ROEit $+\beta_{11}$ LEVit $+\beta_{12}$ AGEit + Cit $(\mathrm{p}>0.10)=$ Not Significant

$*(\mathrm{p} \leq 0.10)=$ Significant at $10 \%$

$* *(\mathrm{p} \leq 0.05)=$ Significant at $5 \%$

$* * *(\mathrm{p} \leq 0.01)=$ Significant at $1 \%$

$* * *$ Significant at $1 \%=(\mathrm{p} \leq 0.01)$,

${ }^{\text {a }}$ Dichotomous variable where $1=$ presence of and $0=$ absence of.

${ }^{\dagger}$ Ln stands for Log transformed variables 
Table 6: Regression results for before the financial crises (DV: LnCCID)

\begin{tabular}{|c|c|c|c|c|}
\hline Variables & $\begin{array}{l}\text { Model 7a } \\
\text { 2004-2005 }\end{array}$ & $\begin{array}{l}\text { Model 7b } \\
\text { 2004-2007 }\end{array}$ & $\begin{array}{c}\text { Model 7c } \\
\text { 2004-2005 with } \\
\text { 1-year lag } \\
\text { LnCOMNEWS }\end{array}$ & $\begin{array}{c}\text { Model 7d } \\
\text { 2004-2007 with 1- } \\
\text { year lag } \\
\text { LnCOMNEWS }\end{array}$ \\
\hline & Coeff (t-stat) & Coeff (t-stat) & Coeff (t-stat) & Coeff (t-stat) \\
\hline LnCOMNEWS & $8.688(1.95) *$ & $0.756(1.09)$ & $10.425(1.95)$ * & $0.213(0.28)$ \\
\hline BODMET & $-0.105(-0.80)$ & $0.023(0.38)$ & $-0.105(-0.80)$ & $0.020(0.32)$ \\
\hline BODCOMP & $-3.352(-1.10)$ & $2.441(2.08) * *$ & $-3.352(-1.10)$ & $2.436(2.07) * *$ \\
\hline BODSIZ & $-0.123(-0.59)$ & $0.071(1.00)$ & $-0.123(-0.59)$ & $0.074(1.05)$ \\
\hline CSRCOM $^{\mathrm{a}}$ & $-0.257(-0.37)$ & $-0.286(-0.82)$ & $-0.257(-0.37)$ & $-0.295(-0.85)$ \\
\hline DISCOM $^{\mathrm{a}}$ & $-1.018(-1.31)$ & $-0.825(-2.35) * *$ & $-1.018(-1.31)$ & $-0.837(-2.38) * *$ \\
\hline RISKCOM $^{\mathrm{a}}$ & $0.503(0.71)$ & $0.340(0.84)$ & $0.503(0.71)$ & $0.344(0.85)$ \\
\hline LnOTHCSRD & $0.053(0.22)$ & 0.415 (3.61) *** & $0.053(0.22)$ & $0.420(3.64) * * *$ \\
\hline $\operatorname{LnMCAP}^{\dagger}$ & $0.616(2.85) * * *$ & $0.371(2.71) * * *$ & $0.616(2.85) * * *$ & $0.365(2.66) * * *$ \\
\hline ROE & $-0.035(-2.39) * *$ & $-0.015(-1.79) *$ & $-0.035(-2.39) * *$ & $-0.015(-1.76) *$ \\
\hline LEV & $-0.058(-2.47) * *$ & $-0.003(-0.45)$ & $-0.059(-2.47) * *$ & $-0.003(-0.39)$ \\
\hline AGE & $-1.583(-1.47)$ & $0.345(3.25) * * *$ & $-1.583(-1.47) * *$ & $0.416(5.02) * * *$ \\
\hline Constant & $112.81(1.88) *$ & $-3.038(-0.396)$ & $-55.02(-2.04) * *$ & $-12.92(-1.91) *$ \\
\hline Adjusted $R^{2}$ & 0.765 & 0.676 & 0.765 & 0.674 \\
\hline F- test & $6.688 * * *$ & $8.316 * * *$ & $6.688 * * *$ & $8.263 * * *$ \\
\hline$N$ & 160 & 320 & 160 & 320 \\
\hline
\end{tabular}

Notes: This table reports the results of our examination of the effect of Community Expectation measured by media coverage on community issues on Community Involvement Disclosures estimated as CCIDit $=\alpha_{0}+\beta_{1}$ COMNEWSit- 1 $+\beta_{2}$ BODMETit $+\beta_{3}$ BODCOMPit $+\beta_{4}$ BODSIZit $+\beta_{5}$ RISKCOMit $+\beta_{6}$ DISCOMit $+\beta_{7}$ CSRCOMit $+\beta_{8}$ OTHCSRDit + $\beta_{9}$ LnMCAPit $+\beta_{10}$ ROEit $+\beta_{11}$ LEVit $+\beta_{12}$ AGEit + Cit

$(\mathrm{p}>0.10)=$ Not Significant

$*(\mathrm{p} \leq 0.10)=$ Significant at $10 \%$

$* *(\mathrm{p} \leq 0.05)=$ Significant at $5 \%$

$* * *(\mathrm{p} \leq 0.01)=$ Significant at $1 \%$

$* * *$ Significant at $1 \%=(\mathrm{p} \leq 0.01)$,

${ }^{\text {a }}$ Dichotomous variable where $1=$ presence of and $0=$ absence of.

${ }^{\dagger}$ Ln stands for Log transformed variables 
Table 7: Regression results for during and after the financial crises (DV: LnCCID)

\begin{tabular}{|c|c|c|c|}
\hline \multirow[t]{2}{*}{ Variables } & $\begin{array}{c}\text { Model 8a } \\
\text { During crisis } \\
\text { 2008-2010 with } \\
\text { LnCOMNEWS }\end{array}$ & $\begin{array}{c}\text { Model 8b } \\
\text { During crisis } \\
\text { 2008-2010 with } \\
\text { 1-year lag of } \\
\text { LnCOMNEWS }\end{array}$ & $\begin{array}{c}\text { Model 8c } \\
\text { After the financial } \\
\text { crisis (2011-2012) }\end{array}$ \\
\hline & Coeff (t-stat) & Coeff (t-stat) & Coeff (t-stat) \\
\hline LnCOMNEWS & $-0.325(-1.00)$ & $-0.029(-0.17)$ & $4.260(2.125) * *$ \\
\hline BODMET & $0.037(1.38)$ & $0.035(1.30)$ & $0.038(1.420)$ \\
\hline BODCOMP & $1.454(1.41)$ & $1.323(1.29)$ & $0.400(0.260)$ \\
\hline BODSIZ & $0.000(0.01)$ & $-0.003(-0.06)$ & $-0.030(-0.505)$ \\
\hline $\mathrm{CSRCOM}^{\mathrm{a}}$ & $-0.246(-1.18)$ & $-0.280(-1.35)$ & \\
\hline DISCOM $^{\mathrm{a}}$ & $0.291(0.91)$ & $0.298(0.92)$ & $0.131(0.223)$ \\
\hline RISKCOM $^{\mathrm{a}}$ & $-0.130(-0.44)$ & $-0.204(-0.72)$ & $0.060(0.100)$ \\
\hline LnOTHCSRD & $0.423(3.48) * * *$ & $0.419(3.44) * * *$ & $0.907(4.222) * * *$ \\
\hline $\operatorname{LnMCAP}^{\dagger}$ & $-0.142(-0.78)$ & $-0.137(-0.73)$ & $-0.242(-2.011) * *$ \\
\hline ROE & $0.005(1.28)$ & $0.005(1.27)$ & $-0.002(-0.743)$ \\
\hline LEV & $-0.001(-0.28)$ & $-0.001(-0.26)$ & $-0.005(-0.839)$ \\
\hline AGE & $0.218(1.04)$ & $0.020(0.32)$ & $0.714(2.089) * *$ \\
\hline Constant & $0.360(0.15)$ & 2.588 (1.47) & \\
\hline Adjusted $R^{2}$ & 0.742 & 0.740 & 0.811 \\
\hline F-test & $8.546 * * *$ & $8.479 * * *$ & $8.568^{* * *}$ \\
\hline$N$ & 240 & 240 & 160 \\
\hline
\end{tabular}

Notes: This table reports the results of our examination of the effect of Community Expectation measured by media coverage on community issues on Community Involvement Disclosures estimated as CCIDit $=\alpha_{0}+\beta_{1}$ COMNEWSit- 1 $+\beta_{2}$ BODMETit $+\beta_{3}$ BODCOMPit $+\beta_{4}$ BODSIZit $+\beta_{5}$ RISKCOMit $+\beta_{6}$ DISCOMit $+\beta_{7}$ CSRCOMit $+\beta_{8}$ OTHCSRDit + $\beta_{9}$ LnMCAPit $+\beta_{10}$ ROEit $+\beta_{11}$ LEVit $+\beta_{12}$ AGEit + Cit

$(\mathrm{p}>0.10)=$ Not Significant

$*(\mathrm{p} \leq 0.10)=$ Significant at $10 \%$

$* *(\mathrm{p} \leq 0.05)=$ Significant at $5 \%$

$* * *(p \leq 0.01)=$ Significant at $1 \%$

$* * *$ Significant at $1 \%=(\mathrm{p} \leq 0.01)$,

${ }^{\text {a }}$ Dichotomous variable where $1=$ presence of and $0=$ absence of.

${ }^{\dagger}$ Ln stands for Log transformed variables 